\title{
Şanlıurfa ilinde üretilen geleneksel yoğurtların mikrobiyotası ve mevzuat açısından değerlendirilmesi
}

\section{The microbiota of traditional yogurts produced in Şanlıurfa and evaluation of the yogurt in terms of legislation}

\author{
Esra ÇETIN ${ }^{1}$ iD, Şerafettin ÇELIK²*iD \\ 1,2 Harran Üniversitesi Mühendislik Fakültesi Gıda Mühendisliği Bölümü Osmanbey Kampüsü, Haliliye-Şanlıurfa \\ ${ }^{1}$ https://orcid.org/0000-0002-4465-1062; ${ }^{2}$ https://orcid.org/0000-0002-5605-5735
}

To cite this article:

Çetin, E. \& Çelik, Ş. (2021). Şanlıurfa ilinde üretilen geleneksel yoğurtların mikrobiyotası ve mevzuat açısından değerlendirilmesi. Harran Tarım ve Gıda Bilimleri Dergisi, 25(3): 406417.

DOI: $10.29050 /$ harranziraat.863182

*Address for Correspondence:
Şerafettin ÇELIK
e-mail:
scelik69@harran.edu.tr

\section{Received Date:}

18.01.2021

Accepted Date:

07.08.2021

(C) Copyright 2018 by Harran University Faculty of Agriculture. Available on-line at www.dergipark.gov.tr/harranziraat

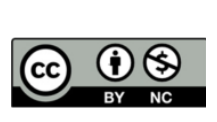
This work is licensed under
a Creative Commons
Attribution-Non
Commercial 4.0
Intermational License.

\section{Öz}

Bu çalışmada, Şanlıurfa il merkezinde tüketime sunulan geleneksel yoğurtların mikrobiyotası ile bazı kimyasal özelikleri çalışılmış ve mevzuat açısından değerlendirilmiştir. Geleneksel yoğurt örneklerinin ortalama titrasyon asitliği \%0.76 $\pm 0.45 \mathrm{LA}, \mathrm{pH}$ değeri $3.96 \pm 0.04$, kurumadde oranı \%13.69 \pm 0.81 , yağ oranı ise $\% 2.30 \pm 1.27$ olarak hesaplanmıştır. Yoğurt örneklerinde çubuk şekilli laktik asit bakteri sayısı $6.02 \pm 0.10$, log kob g ${ }^{-1}$ kok şekilli laktik asit bakteri sayısı $5.79 \pm 0.14 \log k \mathrm{~kb} \mathrm{~g}^{-1}$, maya-küf sayısı $4.55 \pm 0.17 \mathrm{log} \mathrm{kob} \mathrm{g}^{-1}$, koliform grubu bakteri sayısı $1.48 \pm 0.15$ log kob g ${ }^{-1}$ ve $E$. coli sayısı $1.05 \pm 0.04 \log _{\text {kob g }}$-1 $^{-1}$ olarak bulunmuştur. Ayrıca, geleneksel yoğurt florasından alınan toplam 167 adet laktik asit bakteri izolatından 45 adedi Lactococcus sp., 3 adedi Leuconostoc sp., 53 adedi Enterococcus sp., 10 adedi Str. thermophilus, 30 adedi homolaktik Lactobacillus sp. ve 26 adedi ise heterolaktik Lactobacillus sp. olarak tanımlanmıştır. Geleneksel yoğurtların araştırılan kimyasal özellikler bakımından ilgili mevzuat ile uygunluk arz ettiği sonucuna varılmıştır.

Anahtar Kelimeler: Geleneksel yoğurt, mikrobiyota, laktik asit bakterileri, gıda güvenliği, mevzuat

\section{ABSTRACT}

In this study, the microbiota and some chemical properties traditional yoghurts sold in Şanlıurfa city center were investigated and evaluated in terms of legislation. The average titratable acidity and $\mathrm{pH}$ of traditional yoghurt samples were calculated as $\% 0.76 \pm 0.45 \mathrm{LA}$ and $3.96 \pm 0.04$, while the ratios of dry matter and fat of the yogurts were determined as $13.69 \pm 0.81 \%$ and $2.30 \pm 1.27 \%$, respectively. On the other hand, the average counts of basiland coke-shaped lactic acid bacteria, yeast-mold, coliform bacteria and $E$. coli the yogurts were found as $6.02 \pm 0.10$ log cfu g- $1,5.79 \pm 0.14$ log cfu g- $1,4.55 \pm 0.17$ log cfu g-1, 1.48 \pm 0.15 log cfu g-1 1.05 \pm 0.04 log cfu g-1, respectively. In addition, a total of 167 lactic acid bacteria isolates from traditional yogurt flora defined as: 45 of them are Lactococcus sp., 3 of them are Leuconostoc sp., 53 of them are Enterococcus sp., 10 of them are Str. thermophilus, 30 of them are homolactic Lactobacillus sp. and 26 of them are heterolactic Lactobacillus sp. It was concluded that traditional yogurts comply with the relevant legislation in terms of the chemical properties investigated.

Key Words: Traditional yoghurt, microbiota, lactic acid bacteria, food safety, legislation

\section{Giriş}

Yoğurt, fonksiyonel bir gıda olarak değerlendirilmekte ve beslenme açısından önemli bir yere sahip olduğu bilinmektedir. Yoğurdun besleyicilik değeri, süt bileşenlerinin tamamı ile laktik asit bakterileri (LAB) tarafından gerçekleşen fermantasyon sonucu oluşan laktik asit, asetaldehit, aseton ve diasetil gibi çeşitli karbonil 
bileşiklerin bağırsak florası üzerinde olumlu etkilerinin olduğu, hastalıkların önlenmesi veya tedaviye katkı sağladığı bildirilmektedir (Rasic and Kurmann, 1978; Üçüncü, 2005). Ayrıca bu bileşikler, yoğurtta ekşimsi ve serinletici tat-aroma oluşumuna neden olmakta (Şenol ve Elvan, 2014), sentezlenen bakteriyosinler florada bulunabilecek patojen mikroorganizmaların gelişmesini inhibe etmekte, ekzopolisakkaritler ise ürünün tekstürel özelliklerinin gelişmesine katkı sağlamaktadırlar (Axelsson, 2004; Şimşek, 2015).

Günümüz şartlarında, endüstriyel yoğurt üretimde bileşimi ve karakteristik özellikleri bilinen ticari konsantre liyofilize starter kültür (Str. thermophilus ve Lb. delbrueckii ssp. bulgaricus) kullanılmaktadır (Anonim, 2009; Yaygın ve Kılıç, 1993). Ancak geleneksel yoğurt üretimde ise bir önceki üretimden alınan bir parça yoğurt starter kültür olarak kullanılmaktadır. Geleneksel üretimde starter kültür olarak kullanılan yoğurdun mikrobiyal florasının değişkenlik göstermesi nedeniyle, standart tat-aroma ve yapıda yoğurt üretimi gerçekleşmemekte ve yoğurdun raf ömrü değişkenlik göstermektedir (Ceylan ve Biberoğlu, 2013; Demirci ve Elvan, 2020; Durak ve ark., 2008; Herdem, 2006; Hisoğlu, 2007; Koçak, 2013; Türkoğlu ve ark., 2003).

Geleneksel yoğurt üretiminde, yoğurda işlenecek süte değişen sürelerde kaynatma işlemi uygulanmakta, yaklaşık $40{ }^{\circ} \mathrm{C}^{\prime}$ ye kadar soğuması beklenmekte ve bir önceki günden kalan yoğurt ile mayalama işlemi yapılmaktadır. Süte ilave edilecek yoğurt miktarı ile inkübasyon süresi kişisel tecrübeye göre değişmektedir. İnkübasyon sonrası, yoğurt soğuk bir ortama alınmakta ve çoğunlukla hijyenik şartlar oluşturulmadan soğutma, inokülasyon, inkübasyon ve soğutma işlemleri gerçekleştirilmektedir. İnkübasyon ve sonrasında bulaşan çeşitli mikroorganizmalar, yoğurdun tekstür ve tat-aromasında istenmeyen değişikliklere neden olmaktadır (Bakırcı ve ark., 2015; Ceylan ve Biberoğlu, 2013; Demirci ve Elvan, 2020; Durak ve ark., 2008). Endüstriyel yoğurt üretiminde ise, çiğ süte klarifikasyon, standardizasyon, homojenizasyon ve yüksek normda pastörizasyon uygulandıktan sonra, inkübasyon sıcaklığına soğutulmakta, kontrollü ve hijyenik şartlarda inokülasyon ve inkübasyon sonrası yoğurt soğutulmaktadır (Üçüncü, 2005).

Bölgede yaygın bir şekilde tüketilen geleneksel yoğurtlara olan ilgi ve talep zamanla artmaktadır. $\mathrm{Bu}$ durumun, bölge tüketicilerinin damak zevki başta olmak üzere basında bu tür gıdalara olan eğilim ve yönlendirmeden kaynakladığı ifade edilebilir. Diğer taraftan endüstriyel yoğurtların, tat-aroma bakımından bölge tüketicilerinin isteklerini karşılamadığı, bu yoğurtların tatımsı ve aroma bakımından yetersiz olarak algılandığı bilinmektedir (Bakırcı ve ark., 2015; Demirci ve Elvan, 2020). Bu bağlamda, kırsal kesimde geleneksel yoğurt üretiminde kullanılan ve bölgede kara maya olarak anılan bir gün önce üretilen yoğurdun mikrobiyotası ile mikrobiyotayı oluşturan LAB'nin tanımlanması önem taşımaktadır.

$\mathrm{Bu}$ çalışmada, kırsal bölgelerde üretilen ve Şanlıurfa il merkezinde satışa sunulan inek sütünden üretilen geleneksel yoğurt örneklerinin bileşimi, asitlik ve mikrobiyal florasının tespit edilmesi, laktik florayı oluşturan bakterilerin cins düzeyinde tanımlanması ve Türk Gıda Kodeksi Fermente Süt Ürünleri Tebliği'ne (Anonim, 2009) uygunluğunun araştırılması amaçlanmıştır.

\section{Materyal ve Metot}

\section{Materyal}

Şanlıurfa il merkezinde Ocak-Şubat aylarında satışa sunulan toplam 25 adet inek sütünden üretilen geleneksel yoğurt örneği (100 g) steril cam kavanozlara alınmış ve soğuk zincir muhafaza edilerek laboratuvara ulaştırılmıştır.

\section{Metot}

\section{Bazı kimyasal parametreler}

Geleneksel yoğurt örneklerinde kurumadde (KM) ve yağ oranları ile $\mathrm{pH}$ ve titrasyon asitliği (\% laktik asit) tespit edilmiştir (Kurt ve ark., 2014).

\section{Geleneksel yoğurtların mikrobiyotası}

Yoğurt örneklerinden ilk dilüsyon direk yoğurttan $10 \mathrm{~g}$ örnek alınarak $90 \mathrm{~mL}$ steril peptonlu 
su (\%0.1'lik) ile hazırlanmıştır (Caridi, 2003; Gerasi et al., 2003). Daha sonra uygun dilüsyonların hazırlanması amacıyla steril peptonlu su kullanılmıştır.

Yoğurt florasından $L A B$ yükü ve izolasyonu amacıyla, MRS (Merck) ve M17 agar (Merck) besiyerleri kullanılarak yayma yöntemiyle ekim yapılmıştır. Lactobacillus cinsi LAB için MRS agar besiyerine $\left(37^{\circ} \mathrm{C}^{\prime}\right.$ de 48 saat), kok şekilli LAB için ise M17 agar ( $37{ }^{\circ} \mathrm{C}^{\prime}$ de 48 saat) besiyerine ekim yapılarak anaerobik şartlarda inkübasyona bırakılmıştır. Petri plaklarında gelişen bakteriler sayılmıştır. Koliform grubu bakteri sayımı için, dökme plak yöntemiyle VRBA (Merck) besiyerine ekim yapılmış, $35^{\circ} \mathrm{C}^{\prime}$ de 24 saat inkübe edildikten sonra kırmızı renkli koloniler sayılmıştır (Spencer ve de Spencer, 2001). E.coli varlığı ve sayımı için, dökme plak yöntemiyle TBX agar (Oxoid CM945) besiyerine ekim yapılmış, $30{ }^{\circ} \mathrm{C}^{\prime}$ de 4 saat ve 44 ${ }^{\circ} \mathrm{C}$ 'de 18 saat inkübe edilmiş ve yeşil renkli kolonilerin oluşumu gözlemlenmiştir (Vural ve ark., 2010). Maya-küf sayımı için, dökme plak yöntemiyle PDA (Merck) besiyerine (\%10'lük tartarik asit ile $\mathrm{pH}$ 3.5'e ayarlanmış) ekim yapılmış, $20{ }^{\circ} C^{\prime}$ de 5 gün inkübe edilmiş ve oluşan maya-küf kolonileri sayılmıştır (Spencer and de Spencer, 2001).

Laktik asit bakterilerinin izolasyonu ve cins düzeyinde tanımlanması

İnkübasyon sonrası, MRS ve M17 agar besiyerlerinden rastgele olarak en az 5 adet tipik koloni izolatı alınmıştır. Alınan her bir izolat, taze hazırlanmış aynı besiyerine çizme plak yöntemiyle ekim yapılarak saflaştırılmıştır. Daha sonra her bir bakteri kolonisinden, gliserol $(\% 25, \mathrm{w} / \mathrm{v})$ içeren MRS broth (Merck, basiller için) ve M17 broth (Merck, koklar için) besiyerlerine ekim yapıldıktan sonra 24 saat süre ile inkübe edilmiştir. İnkübasyon sonrası kültürler, aseptik şartlarda 2 adet 2 mL'lik cryotüplere aktarılmış ve $-20{ }^{\circ} \mathrm{C}^{\prime}$ de dondurularak stok kültürler oluşturulmuştur (Caridi, 2003; Gerasi et al., 2003). Stok kültürler 25 ppm aktif klor içeren su banyosunda çözdürüldükten sonra takip eden analizler için kullanılmıştır. Stok MRS ve M17 broth besiyerlerinden, taze hazırlanmış aynı besiyerine ekim yapılarak izolatların sıvı kültürleri (24 saat) oluşturulmuştur.

\section{Gram reaksiyonu}

Üzerine bir damla serum fizyolojik damlatılan temiz bir lamın üzerine Gram reaksiyonları incelenecek olan örneklerin saf kültürlerinden steril özeyle alınmış ve kültür lamın üzerinde öze yardımıyla yayılmıştır. Saf kültürler iyice kuruduktan sonra, lamın alt yüzeyi üç kez bunzen beki alevinden geçirilerek bakterilerin lamın üzerine fiksasyonu sağlanmıştır. Preparatın üzerine birkaç damla kristal violet damlatılarak 1-2 dakika bekletilmiştir. Daha sonra preparat lugol çözeltisi ile yıkanarak kristal violetten arındırılmış ve preparat lugol çözeltisi ile tekrar yıkanarak 1-2 dakika bekletilmiştir. Lugol çözeltisini uzaklaştırmak için damıtık su ile yıkama işlemi gerçekleştirilmiştir ve preparatın üzerine $\% 95^{\prime}$ lik etil alkol damlatılarak 10-15 saniye beklenmiştir. Ardından lam, damıtık su ile yıkanıp sulu fuksin çözeltisi damlatılmış ve 20-30 saniye beklenmiştir. Son kez damıtık su ile yıkanan preparat kurutulduktan sonra mikroskopta incelenmiştir. Mor renkli bakteriler Gram (+), pembe renkli bakteriler ise Gram (-) bakteriler olarak değerlendirilmiştir (Halkman, 2005). Gram boyama yapılan izolatlar ışık mikroskobunda morfolojik (kok, basil) olarak sınıflandırılmıştır (Sharpe, 1979).

\section{Katalaz reaksiyonu}

Sıvı veya katı besiyerlerinde geliştirilen bakteri kültürüne $\mathrm{H}_{2} \mathrm{O}_{2}$ ilave edildiğinde, serbest oksijenin gaz kabarcıkları halinde gözlenebilmesi, hidrojen peroksit ayrışmasını, dolayısıyla katalaz enziminin varlığını göstermektedir. Petri kutusundaki agarlı kültür yüzeyine $1 \mathrm{~mL} \% 3$ 'lük $\mathrm{H}_{2} \mathrm{O}_{2}$ ilave edilerek gaz çıkışı olup olmadığı incelenmiştir. Gaz çıkışı gözlenmeyen koloniler Katalaz (-) negatif olarak değerlendirilmiştir (Whittenbury, 1964).

\section{Farklı tuz konsantrasyonlarında gelişebilme}

Bakteri izolatları 20, 40 ve $65 \mathrm{gr} \mathrm{NaCl} \mathrm{L}^{-1}$ içeren M17 broth (\%1.7 bromkrezol purple) besiyerinde inoküle edilmiş ve $28^{\circ} \mathrm{C}$ (mezofiller) veya $42^{\circ} \mathrm{C}$ 'de (termofiller) 4 gün süreyle inkübe edilerek gelişme 
durumları test edilmiştir. Besiyerinin renginin sarıya dönmesi, pozitif sonuç olarak değerlendirilmiştir. Basil şekilli olanlar için böyle bir test uygulanmamıştır (Caridi, 2003; Gerasi et al., 2003; Veljovic et al., 2007).

\section{Farklı sıcaklıklarda gelişebilme}

Bir gecede geliştirilen (24 saat) kültürlerden 50 $\mu \mathrm{l}$ alıp $5 \mathrm{~mL}$ (\%1.7 bromkrezol purple) M17 broth SIVı besiyerine inoküle edilerek inkübasyon (Lactococcus sp. ve Enterococcus sp. bakteriler için (\%1.7 bromkrezol purple) 10 ve $45{ }^{\circ} \mathrm{C}^{\prime}$ de $48-72$ saat) sonunda gelişme durumları test edilmiştir. Besiyerinin renginin sarıya dönmesi, pozitif sonuç olarak değerlendirilmiştir. Basil şekilli olanlar için böyle bir test uygulanmamıştır (Caridi, 2003; Cogan et al., 1997; Gerasi et al., 2003; Veljovic et al., 2007).

\section{Fermantasyon testi}

Fermantasyon testi için, tüplerin içine ters bir şekilde Durham tüpü yerleştirilmiştir. MRS broth ve M17 broth içeren deney tüplerine ekim yapılarak $37{ }^{\circ} \mathrm{C}^{\prime}$ de 48 saat inkübasyon sonrası gaz $\left(\mathrm{CO}_{2}\right)$ oluşumu test edilmiştir. Fermantasyon tipi bakımından test edilmiştir. Gaz oluşumu gözlenen besiyerlerinde, heterofermentatif bakteri varlığı kabul edilmiştir (Caridi, 2003; Gerasi et al., 2003; Veljovic et al., 2007).

\section{Istatistiksel analizler}

Yoğurt örneklerinde araştırılan parametrelere ait veriler, basit istatistiksel değerlendirme sonucunda ortalama ve standart sapmaları hesaplanmıştır (Yıldız ve Bircan, 1994).

\section{Araştırma Bulguları ve Tartışma}

\section{Geleneksel yoğurtların bileşimi}

Şanlıurfa ilinde satışa sunulan geleneksel inek yoğurdunun KM ve yağ oranları, $\mathrm{pH}$ ve titrasyon asitliği ile ilgili veriler Çizelge $1^{\prime}$ de verilmiştir.

Şanlıurfa ilinde tüketime sunulan geleneksel inek yoğurdunun ortalama KM oranı \%13.69 \pm 0.81 olarak hesaplanmıştır (Çizelge 1). Geleneksel yoğurdun KM oranının düşük olması, yağ oranının düşük olmasından kaynaklandığı düşünülmektedir. Konya (Herdem, 2006), Ağrı (Hisoğlu, 2007), Erzurum ve Kars (Ceylan ve Biberoğlu, 2013), Batman (Karahan, 2016) ve Erzurum (Karacaoğlu, 2018) illerinde yapılan çalışmalarda, bu illerde üretilen geleneksel yoğurtların KM oranı (\%), sırasıyla 12.19, 14.37, 13.02, 13.70 ve 13.79 olarak bildirilmiştir. Bu çalışmada elde edilen KM oranı, literatür bildirimleri ile uygunluk arz etmektedir. Genel olarak geleneksel yoğurtlarda KM oranı düşük bulunmuştur. Bu durum, yoğurt üretiminde kullanılan süt türü, üretim prosesinde bir miktar süt yağının çekilmesi veya KM standardizasyonunun yapılmaması gibi etkenlerden kaynaklandığı düşünülmektedir.

Geleneksel yoğurdun yağ oranı \%0.5-4.0 arasında değişmiş ve ortalama \%2.30 \pm 1.27 olarak bulunmuştur (Çizelge 1). Yapılan literatür araştırmasında, Konya (Herdem, 2006), Erzurum (Bakırcı ve ark., 2015), Batman (Karahan, 2016), Erzurum (Karacaoğlu, 2018), Van (Tolu, 2019) ve Balıkesir (Tavşanlı ve ark., 2020) illerinde üretilen geleneksel yoğurtların ortalama yağ oranları (\%) sırasıyla $3.87,2.87,4.4,2.90,4.23$ ve 3.06 olarak bildirilmiştir. Bu çalışmada Şanlıurfa ilinde tüketime sunulan geleneksel yoğurtların ortalama yağ oranı, literatür bildirimlerinden daha düşük bulunmuştur. Geleneksel yoğurt üretiminde, açık kazanda süte yüksek normda ısıl işlem (daha çok kaynatma işlemi) uygulanması nedeniyle, oransal olarak sütün yağ ve KM oranları yükselmektedir. Dolayısıyla, tam yağlı yoğurt üretilmesi beklenmektedir. Ancak, Şanlıurfa ilinde tüketime sunulan yoğurdun bileşimindeki yağ oranının düşük olduğu tespit edilmiştir. Bu durumun, yoğurt üretiminde kullanılan sütten bir miktar yağın alınmasından kaynaklandığı, bu bağlamda sütten alınan yağın, kaymak, tereyağı ve sadeyağ olarak değerlendirildiği düşünülmektedir. Şanlıurfa ilinde market ve perakende satış noktalarında kahvaltılık kaymak, tereyağı ve sadeyağ satışının yaygın olduğu gözlenmektedir. 
Çizelge 1. Şanlıurfa ilinde satışa sunulan inek sütünden üretilen geleneksel yoğurtların bazı kimyasal ve mikrobiyolojik parametrelerine ilişkin en düşük, en yüksek ve ortalama değerler

Table 1. The lowest, highest and average values for some chemical and microbiological parameters of traditional yoghurts produced from cow milk offered for sale in the province of Şanlıurfa

\begin{tabular}{|c|c|c|c|}
\hline $\begin{array}{l}\text { Parametre } \\
\text { Parameter }\end{array}$ & $\begin{array}{l}\text { En düşük } \\
\text { The lowest }\end{array}$ & $\begin{array}{l}\text { En yüksek } \\
\text { The highest }\end{array}$ & Ortalama \\
\hline $\begin{array}{l}\text { Parameter } \\
\text { Kurumadde, \% }\end{array}$ & $\begin{array}{c}\text { The lowest } \\
12.48\end{array}$ & $\begin{array}{c}\text { The highest } \\
15.67\end{array}$ & $\begin{array}{c}\text { Average } \\
13.69 \pm 0.81\end{array}$ \\
\hline Drymatter, \% & 12.48 & 15.67 & $13.69 \pm 0.81$ \\
\hline $\begin{array}{l}\text { Yağ, \% } \\
\text { Fat, \% }\end{array}$ & 0.5 & 4.0 & $2.30 \pm 1.27$ \\
\hline $\mathrm{pH}$ & 3.64 & 4.32 & $3.96 \pm 0.04$ \\
\hline $\begin{array}{l}\text { Titrasyon asitliği, \% laktik asit } \\
\text { Titratable acidity, \% lactic acid }\end{array}$ & 0.40 & 2.17 & $0.76 \pm 0.45$ \\
\hline $\begin{array}{l}\text { Laktik asit bakterileri (M17 agar), log kob g-1 } \\
\text { Lactic acid bacteria (M17 agar), log cfu g }\end{array}$ & 4.52 & 6.97 & $5.79 \pm 0.14$ \\
\hline $\begin{array}{l}\text { Laktik asit bakterileri (MRS agar), log kob g-1 } \\
\text { Lactic acid bacteria (M17 agar), log cfu g }\end{array}$ & 5.00 & 6.70 & $6.02 \pm 0.10$ \\
\hline $\begin{array}{l}\text { Koliform grubu bakteriler, log kob g }{ }^{-1} \\
\text { Coliform bacteria, } \log \mathrm{cfu} \mathrm{g}^{-1}\end{array}$ & $<1$ & 2.91 & $1.48 \pm 0.15$ \\
\hline $\begin{array}{l}\text { E. coli, log kob g-1 } \\
\text { E. coli, log cfu g-1 }\end{array}$ & $<1$ & 1.96 & $1.05 \pm 0.04$ \\
\hline $\begin{array}{l}\text { Maya-küf, log kob g }{ }^{-1} \\
\text { Yeast and molds, log cfu g }\end{array}$ & 2.88 & 6.03 & $4.56 \pm 0.17$ \\
\hline
\end{tabular}

Türk Gıda Kodeksi Fermente Süt Ürünleri Tebliği'nde (Anonim, 2009) yağ oranı bağlamında yoğurt, tam yağlı (süt yağı $\geq \% 3.8$ ), yarım yağlı (\%2.0 > süt yă̆ı $\geq \% 1.5$ ) ve yağsız (süt yağı $\leq \% 0.5$ ) yoğurt olarak sınıflandırımış, ayrıca belirtilen sınıflar dışında kalan yoğurdun ise etiket üzerinde yağ oranının yazılması gerektiği belirtilmiştir. Anılan tebliğ bağlamında, Şanlıurfa ilinde tüketime sunulan geleneksel yoğurt örneklerinin $\% 16^{\prime}$ sı tam yağlı (4 örnek), \%16'sı yarım yağlı (4 örnek), \%5’i yağsız yoğurt ( 5 örnek) sınıfında, \%0.08'i \%1.0 yağlı (2 örnek), \%40'ı ise \%2.4-3.5 yağlı yoğurt (10 örnek) olduğu anlaşılmaktadır.

\section{Geleneksel yoğurtların asitliği}

Şanlıurfa il merkezinde perakende olarak satışa sunulan yoğurtlarda pH değeri 3.64-4.32 aralığında değişmiş, ortalama olarak pH $3.96 \pm 0.04$ olarak bulunmuştur.

Türkoğlu ve ark. (2003) Şanlıurfa ilinde satışa sunulan yoğurdun $\mathrm{pH}$ değerini 3.31-4.16; Ceylan ve Biberoğlu (2013) geleneksel yöntemlerle üretilen yoğurtların pH değerini 3.43-4.19; Çetin ve ark. (2014) Kırklareli ve civar illerde üretilen 26 adet yoğurt örneğinin $\mathrm{pH}$ değerini 3.90-5.25; Karahan (2016) Batman ili merkez köylerinden toplanan 20 yoğurt örneğinin ortalama $\mathrm{pH}$ değerini 3.88; Karacaoğlu (2018) yoğurt örneklerinin pH değeri
4.60-5.39 ve ortalama 4.95 olarak bildirmiştir. Bu çalışmada, Şanlıurfa ilinde satışa sunulan geleneksel yoğurda ait $\mathrm{pH}$ değeri, literatür bildirimleri ile benzerlik göstermektedir. Geleneksel olarak, kırsal kesimde üretilen yoğurtlarda soğuk zincirin kırılması veya yeterli düzeyde uygulanamaması, satış ortamında değişen sıcaklıklarda, uzun süre muhafaza edilmesi sonucu, yoğurdun $\mathrm{pH}$ değeri hızla azalmakta ve buna bağlı olarak raf ömrü kısalmaktadır.

Titrasyon asitliğinin yoğurdun tat-aromasını etkilediği ve yoğurdun tüketilebilme özelliğini kaybetmeden saklanabileceği sürenin belirlenmesinde etkili bir faktör olduğu bilinmektedir (Üçüncü, 2005). Geleneksel yoğurt örneklerinin titrasyon asitliği değerleri Çizelge 1'de verilmiştir. Herdem (2006) farklı yörelerden toplanan geleneksel yoğurt örneklerinin titrasyon asitliğini \%0.96-1.73 LA; Demirkaya ve Ceylan (2013) Bilecik ilinde satışı yapılan 30 adet yoğurt örneğinin titrasyon asitliğini (\% laktik asit) \%0.721.17; Çetin ve ark. (2014) Kırklareli ve civar illerinde satışa sunulan 26 adet yoğurt örneğinin titrasyon asitliğini (\% laktik asit) \%0.10-1.88 aralığında bildirmişlerdir. Karahan (2016) Batman ili merkez köylerinden toplanan 20 yoğurt örneğinin titrasyon asitliğini (\% laktik asit) ortalama \%0.996 olarak bildirmiştir. Araştırıcı, yoğurt örneklerinin 
\%55'inin Türk Gıda Kodeksi Fermente Süt Ürünleri Tebliği bağlamında kriterleri sağlamadığını belirlemiştir. Karacaoğlu (2018) tarafından yoğurt örneklerinin titrasyon asitliğinin \%0.93-1.55 laktik asit arasında değiştiği ve ortalama \%1.31 laktik asit olduğu bildirilmiştir. Şanlıurfa ilinde satışa sunulan geleneksel yoğurdun titrasyon asitliği, literatür bildirimleri ile benzerlik göstermektedir. Yoğurt örneklerinde titrasyon asitliğinin geniş bir aralıkta değişim göstermesi, kullanılan geleneksel yoğurt kültürü (bir önceki günün yoğurdu) bakteri bileşiminin farklı olması, inkübasyon sıcaklığı ve süresinin farklılık göstermesi, üretim-satış aşamalarında muhafaza sıcaklığının değişkenlik göstermesinden kaynaklamış olabilir.

Türk Gıda Kodeksi Fermente Süt Ürünleri Tebliği'ne göre titrasyon asitliğinin (\% laktik asit) yoğurtta en az \%0.6, en fazla ise $\% 1.5$ olabileceği bildirilmiştir (Anonim, 2009). Bu tebliğ bağlamında, analize alınan 25 adet yoğurt örneğinden 3 adet örneğin titrasyon asitliği (\%laktik asit) >\%1.5 değerinden büyük, 5 adet örneğin asitliği ise >\%0.6 değerinden düşük olmak üzere, toplam 8 adet geleneksel yoğurt örneği kriteri sağlayamamaktadır.

\section{Geleneksel yoğurtların laktik asit bakteri florası}

Şanlıurfa ilinde satışa sunulan geleneksel yoğurdun mikrobiyotası (log kob g ${ }^{-1}$ ), Çizelge $1^{\prime}$ de verilmiştir.

Şanlıurfa ili kırsal bölgelerde küçük ev işletmelerinde üretilen ve il merkezinde satışa sunulan yoğurtlarda kok şekilli (Lactococcus sp., Leuconostoc sp., Streptococcus sp. ve Enterococcus $s p$.) toplam LAB yükü (M17 agar) ortalama olarak 5.79 \pm 0.14 log kob g-1 olarak bulunmuştur (Çizelge 1). Yapılan benzer çalışmalar incelendiğinde, farklı yörelerden toplanan geleneksel yoğurt örneklerinin LAB (M17 agar) yükü $1.06 \times 10^{5}$ $1.31 \times 10^{8} \mathrm{kob} \mathrm{g}^{-1}$ (Herdem, 2006), Erzurum ilinde üretilen geleneksel yoğurdun $L A B$ yükü ise 5.257.15 log kob g ${ }^{-1}$ arasında değişmiş ve ortalama 6.20 log kob g-1 (Karacaoğlu, 2018), başka bir çalışmada ise Erzurum bölgesinde üretilen geleneksel yoğurdun florasında ortalama Str. thermophilus

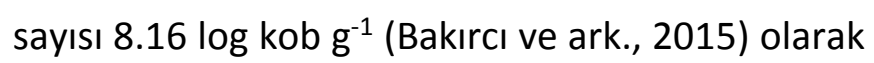

bildirilmiştir. Balıkesir ilinde geleneksel yöntemlerle üretilen yoğurt florasında Lactococcus sp. sayısı 7.89 log kob g-1 olarak bildirilmiştir (Tavşanlı ve ark., 2020). Yapılan çalışmalar kıyaslandığında, genel olarak birbirine yakın sonuçlar elde edilmiştir.

Şanlıurfa ilinde tüketime arz edilen geleneksel yoğurtların çubuk şekilli (Lactobacillus sp.) laktik asit bakteri yükü (MRS agar) 5.00-6.70 log kob g-1 aralığında değişmiş ve ortalama $6.02 \pm 0.10$ log kob $\mathrm{g}^{-1}$ olarak bulunmuştur (Çizelge 1). Güler-Akın (2005) yaptıkları çalışmada yoğurtta $L b$. delbrueckii ssp. bulgaricus sayısın $5.50 \times 10^{8} \mathrm{kob} \mathrm{g}^{-1}$, Herdem (2006) farklı yörelerden toplanan geleneksel yoğurt örneklerinde (MRS agar) LAB yükünü $5.22 \times 10^{5}-6.11 \times 10^{8} \mathrm{kob} \mathrm{g}^{-1}$, Bakırcl ve ark. (2015) Erzurum bölgesinde üretilen yoğurtta ortalama $L b$. bulgaricus sayısını $8.50 \log$ kob g ${ }^{-1}$, Karacaoğlu (2018) yoğurt örneklerinde (MRS agar) LAB sayısını 3.09-7.25 log kob g ${ }^{-1}$ ve ortalama 4.71 log kob g ${ }^{-1}$ olarak bildirmişlerdir. Balıkesir ilinde üretilen geleneksel yoğurtların ortalama Lactobacillus $s p$. sayısı, 7.64 log kob g ${ }^{-1}$ olarak bildirilmiştir (Tavşanlı ve ark., 2020).

Ülkemizde, geleneksel yoğurt üretiminde genellikle bir gün önce üretilen ve tat-aroma bakımından beğenilen yoğurt, bir sonraki üretimde starter kültür olarak kullanılmaktadır (Kişisel görüşmeler). Geleneksel kültür olarak kullanılan yoğurdun özellikle inkübasyon sıcaklığı, süresi ve muhafaza sıcaklığı başta olmak üzere, üretim prosesi farklılık gösterdiğinden dolayı, doğal olarak LAB florası da değişkenlik gösterecektir (Cogan et al., 1997; Stiles and Holzapfel., 1997; Axelsson, 2004). Bu nedenle, ardışık olarak üretilen günlük yoğurtların tat-aroma ve yapısal özelliklerinin de farklılık göstermesi doğal olarak karşılanmaktadır.

Türk Gıda Kodeksi Fermente Süt Ürünleri Tebliği'nde yoğurt, fermantasyonda spesifik olarak Str. thermophilus ve $L b$. delbrueckii subsp. bulgaricus'un simbiyotik kültürlerinin kullanıldığı fermente süt ürünü olarak tanımlanmış ve yoğurt florasında, toplam spesifik mikroorganizma sayısının (starter kültür bakterileri) en az 7 log kob $\mathrm{g}^{-1}$ olabileceği hükme bağlanmıştır (Anonim, 2009). Bu bağlamda gerek M17 agar ve gerekse MRS agar 
besiyerinde gelişen en yüksek LAB yükünün anılan tebliğde belirtilen limitin altında kaldığı, ortalama $L A B$ yükünün ise 5.79 $\pm 0.14-6.02 \pm 0.10 \mathrm{log} \mathrm{kob} \mathrm{g}^{-1}$ olduğu ve bu değerlerin tebliğde belirtilen en düşük yükün çok altında olduğu tespit edilmiştir. $\mathrm{Bu}$ durum, geleneksel yoğurt florasında ticari yoğurt starter kombinasyonunda yer alan bakteriler dışında diğer LAB ile istenmeyen kontaminantların da olmasından kaynaklanmış olabilir.

Geleneksel yoğurtların istenmeyen kontaminant varlığı

\section{Koliform grubu bakteriler}

Şanlıurfa ili kırsal bölgelerinde üretilen ve şehir merkezinde çeşitli satış noktalarında satışa sunulan geleneksel yoğurt florasında, koliform grubu bakteri sayısı <1-2.91 log kob $\mathrm{g}^{-1}$, ortalama $1.48 \pm 0.15$ log kob g-1 olarak bulunmuştur (Çizelge 1). Türkoğlu ve ark. (2003) Şanlıurfa'da tüketilen 20 adet yoğurt örneklerinden sadece 1 adedinde $2.0 \times 10^{3}$ kob $\mathrm{g}^{-1}$ düzeyinde koliform bakteri bulunurken diğer örneklerde belirlenebilir seviyenin altında $\left(<10 \mathrm{kob} \mathrm{g}^{-1}\right)$ koliform bakteri ile karşılaşılmıştır. El-Diasty and El-Kaseh (2009) ElBedia şehrinde toplanan yoğurt örneklerinde $1 \times 10^{2}-4.6 \times 10^{4}$ EMS $\mathrm{g}^{-1}$ arasında ve ortalama $6.0 \times 10^{3}$ EMS $\mathrm{g}^{-1}$ koliform bakteri saptanmıştır. Sömer ve Kılıç (2012) farklı illerde açık pazarlardan topladıkları süzme yoğurt örneklerinde 5.96-6.29 log EMS g-1 koliform bakteri tespit etmişlerdir. Karacaoğlu (2018) ulusal düzeyde üretim yapan ticari firma yoğurtlarında koliform grubu bakterinin tespit edilmediğini, bölgesel olarak üretilen geleneksel yoğurt üretimi yapan firma yoğurt örneklerinin tümünde tebliğde bildirilen limitlerin üzerinde koliform grubu bakteri tespit edildiğini bildirmiştir. Tavşanlı ve ark. (2020) ise, Balıkesir ilinde geleneksel metotlarla üretilen ve halk pazarlarında satışa sunulan yoğurt örneklerinin yoğurt florasında ortalama olarak koliform sayısını 140 EMS g-1 olarak bildirmişlerdir. Diğer taraftan, Konya yöresinde üretilen taze ev yapımı yoğurtların mikrobiyolojik özellikleri bakımından ilgili mevzuat ile uyumluluk arz etmediği bildirilmiştir (Durak ve ark., 2008).
Türk Gıda Kodeksi Fermente Süt Ürünleri yoğurt florasında, koliform bakteri yükünün 9-95 $\mathrm{EMS} \mathrm{g}^{-1}$ olabileceği bildirilmiştir (Anonim, 2009). Geleneksel yoğurt örneklerden 7 adedi, anılan tebliğ ile uyumlu olmadığı belirlenmiştir. Bu durum, üretim sonrası depolama, taşıma ve perakende satış aşamalarında kontaminasyonun olduğunu göstermektedir.

\section{Escherichia coli yükü}

Kırsal bölgelerde üretilen ve Şanlıurfa il merkezinde satışa sunulan 25 adet geleneksel yoğurdun florasında E.coli sayısı <1-1.96 log kob g ${ }^{-1}$ aralığında değişmiş ve ortalama $1.050 \pm 0.04 \mathrm{log}$ kob $\mathrm{g}^{-1}$ olarak bulunmuştur (Çizelge 1). Hisoğlu (2007) tarafından evlerde üretilen yoğurtların $E$. coli sayısı $<0.30-1.50$ EMS $\mathrm{g}^{-1}$ arasında tespit

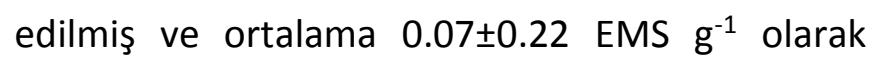
bildirilmiştir. Bölgesel mandıralarda üretilen yoğurtların $E$. coli sayısı ise $<0.30-1.20 \mathrm{EMS} \mathrm{g}^{-1}$ ve ortalama $0.12 \pm 0.27$ EMS $\mathrm{g}^{-1}$ olarak tespit edilmiştir. Koçak (2013) marketlerde satışa sunulan 14 ulusal, 6 yerel olmak üzere 20 yoğurt örneğinde E.coli bakterisine rastlanılmadığını bildirmiştir. Akarca ve Tomar (2019) Afyonkarahisar ili pazarlarında tam yağı süzme veya kese yoğurt örneklerinin 8 adedinde $E$. coli tespit edildiğini, Tavşanlı ve ark. (2020) ise Balıkesir ilinde halk pazarlarında satışa sunulan geleneksel yoğurt örneklerinin E. coli sayısını ortalama 112 EMS g-1 olarak bildirilmişlerdir.

Türk Gıda Kodeksi Fermente Süt Ürünleri Tebliği'nde yoğurt florasında, $E$. coli yükünün $<3$ $\mathrm{EMS}^{-1}\left(10^{-1}\right.$ l'lik dilüsyondan 3 tüpe yapılan ekimde bakteri sayılamaması) olması gerektiği bildirilmiştir (Anonim, 2009). Bu bağlamda, toplanan 25 adet geleneksel yoğurt örneğinden sadece 2 adet örneğin anılan tebliğ ile uyumlu olmadığı, başka bir ifade ile E.coli bakterisi içerdiği tespit edilmiştir. Bu durum, özellikle depolama, taşıma ve perakende satış aşamalarında kontaminasyon olduğu sonucuna varılmıştır. 


\section{Maya-Küf yükü}

Şanlıurfa il merkezinde satışı sunulan 25 adet geleneksel yoğurt florasında maya-küf sayısı Çizelge 1 'de verilmiştir. Yüksek sayıda maya-küf varlığı, geleneksel yoğurt üretiminde inkübasyon sonrası kontaminasyon olduğunu göstermektedir. Bu durumun, yoğurdun kalitesini olumsuz yönde etkilediği düşünülmektedir. Herdem (2006) farklı yörelerden geleneksel yöntemlerle üretilen yoğurt örneklerinde küf-maya sayısı $1.56 \times 10^{6}-4.67 \times 10^{7}$ kob $\mathrm{g}^{-1}$ arasında bulunmuştur. Demirkaya ve Ceylan (2013) Bilecik ilinde satışa sunulan 30 adet yoğurt örneğinde maya ve küf sayısını <1.00-5.87 log kob g ${ }^{-1}$ olarak bildirmişlerdir. Bakırcı ve ark. (2015) Erzurum bölgesinde satışa sunulan 40 adet yoğurt örneğinin fiziksel, kimyasal, mikrobiyolojik ve duyusal özelliklerini araştırmışlardır. Yapılan mikrobiyolojik incelemelerde, ortalama maya ve küf sayısını 4.12 log kob g ${ }^{-1}$ olarak belirlemişlerdir. Karacaoğlu (2018) yapmış olduğu çalışmada, yoğurt florasında maya ve küf sayısının <1-2.37 log $\mathrm{kob} \mathrm{g}^{-1}$ arasında değiştiğini bildirmiştir. Van ilinde satışa sunulan geleneksel yoğurtların ortalama maya-küf sayısı 3.63 log kob g ${ }^{-1}$ olarak bildirilmiştir (Tolu, 2019).

Türk Gıda Kodeksi Fermente Süt Ürünleri Tebliği'nde yoğurt florasında bulunmasına müsaade edilen maya ve küf yüklerinin en fazla 3 log kob g-1 olabileceği bildirilmiştir (Anonim, 2009). Geleneksel yoğurt örneklerinin maya ve küf yükleri açısından anılan tebliğ ile uyumlu olmadığı tespit edilmiştir. Bu durum, yoğurt asitliğinin yükselmesi sonucu yoğurt florasında maya aktivitesinin artması, ayrıca yoğurtların açık ortamda perakende olarak satışa sunulması sonucu florada küf sayısının artması ile izah edilebilir.

\section{Laktik asit bakteri florasının tanımlanması}

Şanlıurfa ilinde satışa sunulan geleneksel yoğurtların LAB florası, cins düzeyinde tanımlanmıştır (Cogan et al., 1997). Bu bağlamda, yoğurt örneklerinden izole edilen toplam 309 adet bakteri izolatından Gram (+) ve Katalaz (-) olan 167 adet $L A B$ izolatının cins/tür düzeyinde dağılımı Çizelge 2'de verilmiştir.

Geleneksel yoğurt örneklerinden M17 ve MRS agar besiyerlerine ekim yapılarak $37{ }^{\circ} \mathrm{C}^{\prime} \mathrm{de}$ inkübasyona terk edilmiş ve farklı morfolojik özellikle toplam 309 adet LAB izolatı alınmıştır. Alınan bu izolatlar, Gram reaksiyonu ve katalaz testine tabi tutulmuştur. Bu izolatlardan 111 adet kok ve 56 adet basil olmak üzere toplam 167 izolat Gram (+) ve Katalaz (-) olarak tanımlanmıştır. Basil cinsi $L A B^{\prime} i$, sadece fermantasyon tipi temelinde tanımlandığı için, farklı tuz konsantrasyonlarında gelişme durumu sadece kok şekilli izolatlara uygulanmıştır. Bu bağlamda, toplam 111 adet LAB izolatı, farklı tuz konsantrasyonları (20, 40 ve $65 \mathrm{~g}$ $\mathrm{NaCl} \mathrm{L}^{-1}$ ) ve \%1.7 ( $\mathrm{g} \mathrm{w}^{-1}$ ) bromkrezol purple içeren M17 broth besiyerinde ( $37^{\circ} \mathrm{C}^{\prime}$ de 4 gün) gelişme durumları test edilmiştir. Bu test sonucunda (kok şekilli), tüm izolatların (111 adet) $20 \mathrm{~g} \mathrm{NaCl} \mathrm{L}^{-1}$ içeren M17 broth besiyerinde geliştiği, \%89.2 (99 adet) izolatın $40 \mathrm{~g} \mathrm{NaCl} \mathrm{L}^{-1}$ içeren M17 broth besiyerinde geliştiği ve \%47.8 (53 adet) izolatın ise aynı zamanda $65 \mathrm{~g} \mathrm{NaCl} \mathrm{L}^{-1}$ içeren M17 broth besiyerinde geliştiği tespit edilmiştir.

Toplam 111 adet kok şekilli LAB izolatı, $10{ }^{\circ} \mathrm{C}$ 'de 7 gün ve $45^{\circ} \mathrm{C}^{\prime}$ de 2 gün süre ile $\% 1.7$ bromkrezol purple içeren M17 broth besiyerinde gelişme durumu test edilmiştir. Inkübasyon sonucunda besiyeri renginin sarıya dönmesi, pozitif sonuç olarak değerlendirilmiştir. Test sonucu, 111 adet kok şekilli bakteri izolatlarından \%91 (101 adet) izolat $10{ }^{\circ} \mathrm{C}^{\prime}$ de ve \%56.8 (63 adet) izolat ise 45 ${ }^{\circ} \mathrm{C}$ 'de gelişme göstermiştir.

Farklı sıcaklık (10 ve $\left.45{ }^{\circ} \mathrm{C}\right)$ ve tuz konsantrasyonunda $\left(2.0,4.0\right.$ ve $\left.6.5 \mathrm{~g} \mathrm{NaCl} \mathrm{L}^{-1}\right)$ gelişme durumlarına bağlı olarak, kok şekilli izolatlar (Lactococcus sp., Enterococcus sp. ve Streptococcus sp.) ayırt edilebilmektedir (Carr et al., 2002; Schleifer et al., 1985). LAB izolatlarından

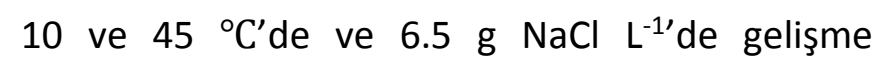
gösterenler Enterococcus sp. olarak tanımlanmaktadır (Cogan et al., 1997).

Fermentasyon testi ise hem kok hem de basil şekilli bakterilere uygulanmıştır. Bu bağlamda, 111 adet kok ve 56 adet basil şekilli olmak üzere toplam 167 adet bakteri izolatı, M17 (kok) ve MRS (basil) broth besiyerinde gaz oluşturma durumları test edilmiştir. Besiyerinde ters şekilde konumlandırılmış Durham tüpünde gaz varlığı 
tespit edilen izolatlar heterofermentatif, gaz çıkışı gözlenmeyen izolatlar ise homofermentatif olarak değerlendirilmiştir (Caridi, 2003; Gerasi et al., 2003; Veljovic et al., 2007). Test sonucunda, \%96.4
(107 adet) kok şekilli izolat ile \%53.6 (30 adet) basil şekilli izolatın homofermentatif olduğu tespit edilmiştir.

Çizelge 2. Şanlıurfa ilinde satışa sunulan inek sütünden üretilen geleneksel yoğurtların laktik asit mikrobiyotası Table 2. Lactic acid microbiota of traditional yoghurts produced from cow's milk sold in the province of Şanlıurfa

\begin{tabular}{|c|c|c|c|c|c|c|c|c|}
\hline \multirow[t]{2}{*}{ 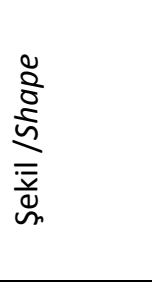 } & \multirow{2}{*}{ 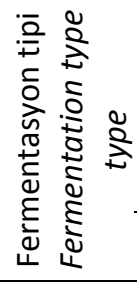 } & \multicolumn{3}{|c|}{$\begin{array}{c}\text { Farklı tuz } \\
\text { konsantrasyonunda } \\
\text { gelişme }\left(\mathrm{g} \mathrm{L}^{-1}\right) \\
\text { Growth in different salt } \\
\text { concentration }\left(\mathrm{g} \mathrm{L}^{-1}\right)\end{array}$} & \multicolumn{2}{|c|}{$\begin{array}{l}\text { Farklı sıcaklıkta } \\
\text { gelişme }\left({ }^{\circ} \mathrm{C}\right) \\
\text { Growth in different } \\
\text { temperature }\left({ }^{\circ} \mathrm{C}\right)\end{array}$} & \multirow[t]{2}{*}{$\begin{array}{c}\text { İzolat sayısı } \\
\text { Number of } \\
\text { isolates }\end{array}$} & \multirow{2}{*}{$\begin{array}{l}\text { Tanımlama } \\
\text { Identification }\end{array}$} \\
\hline & & 20 & 40 & 65 & 10 & 45 & & \\
\hline Kok & - & + & $+/-$ & - & + & - & 45 & Lactococcus sp. \\
\hline Kokobasil & + & + & $+/-$ & - & + & - & 3 & Leuconostoc sp. \\
\hline Kok & - & + & + & + & + & + & 53 & Enterococcus sp. \\
\hline Kok & - & + & - & - & - & + & 10 & Str. thermophilus \\
\hline Basil & - & & & & & & 30 & Homolaktik Lactobacillus sp. \\
\hline Basil & + & & & & & & 26 & Heterolaktik Lactobacillus sp. \\
\hline
\end{tabular}

Uygulanan tüm bu testler sonucunda, Şanlıurfa il merkezinde perakende olarak satışa sunulan geleneksel yoğurtların LAB florasından izole edilen Gram (+) Katalaz (-) toplam 167 izolattan, \%40.5 (45 adet) Lactococcus sp., \%2.7 (3 adet) Leuconostoc sp., \%47.7 (53 adet) Enterococcus sp., \%9'u (10 adet) Str. thermophilus, \%53.6 (30 adet) homolaktik Lactobacillus sp. ve $\% 46.4$ (26 adet) ise heterolaktik Lactobacillus sp. olarak tanımlanmıştır. Cins düzeyinde LAB'nin 17 gruptan oluştuğu, ancak bunlardan Lactobacillus, Lactococcus, Leuconostoc ve Streptococcus cinsi bakterilerin fermente süt ürünlerinin üretiminde kullanılan starter kültür kombinasyonlarında yer aldığı bilinmektedir (Albayrak, 2017; Stiles and Holzapfel, 1997).

Fermente süt teknolojisi bakımından, Lactococcus cinsi bakterilerden sadece Lc. lactis türleri önem taşımakta, tereyağı, krema ve bazı peynir çeşitleri gibi ürünlerin üretiminde kullanılan starter kültür bileşimlerinde yer almaktadırlar (Samaržija et al., 2001; Schleifer et al., 1985; Stiles and Holzapfel, 1997). Diğer taraftan heterofermentatif nitelikte olan Leuconostoc cinsi bakteriler, sitratı metabolize etmeleri nedeniyle, krema ve tereyağı üretiminde kullanılan starter kültür bileşimlerinde yer alırlar ve tereyağının hâkim aromasını oluşturan diasetili sentezlerler (Cogan et al., 1997). Str. thermophilus bakterisi ise, yoğurt, Kaşar peyniri, bazı İtalyan ve İsviçre tipi sert peynir çeşitlerin üretiminde kullanılan starter kültür bileşiminde yaygın olarak kullanılmaktadır (Cogan et al., 1997; Nielsen et al., 2009). Lactobacillus cinsi bakterilerden homofermantatif olan Lb. delbrueckii ssp. delbrueckii, Lb. delbrueckii ssp. bulgaricus ve Lb.delbrueckii ssp. lactis ile $L b$. helveticus ve $L b$. acidophilus türleri fermente süt ürünlerinin üretiminde kullanılan starter kültür bileşimlerinde yer almaktadırlar (Cogan et al., 1997; Kitazawa et al., 2000; Mama et al., 2002).

Ticari starter kültür bileşimlerinde henüz yer almayan Enterococcus cinsi bakterilerden $E$. faecium, E. faecalis ve $E$. durans türleri, fermente süt ürünleri florasında yaygın olarak bulunmaktadırlar (Giraffa, 2003). Bu bakteriler, biyojen amin sentezlemeleri (Göncü ve ark., 2017), ortam asitliğine katkı yapmaları, sitratı metabolize etmeleri, proteolitik ve lipolitik aktiviteye sahip olmaları ve bakteriyosin sentezlemelerinden dolayı, fermente gıda ürünlerinde önem taşımaktadırlar (Moreno et al., 2006).

Ticari yoğurt üretiminde kullanılan starter kültürlerin bileşiminde Str. thermophilus ve $L b$. delbrueckii ssp. bulgaricus yer almaktadır. Yapılan bu çalışmada, anılan bu iki bakteri cinsi/türü dışında, LAB ile birlikte diğer mikroorganizmaların bulunma ihtimalinin yüksek olması beklenen bir durumdur. Nitekim, LAB gelişimine spesifik olan 
M17 ve MRS agar kullanılmasına rağmen, bu besiyerlerinden elde edilen 309 adet izolatın toplam 167 adedinin LAB izolatı ( $\mathrm{G}+$ ve $\mathrm{K}$-) olması önem taşımaktadır. Bununla beraber, ticari starter kültür bileşiminde yer alan LAB dışında ticari yoğurt florasında termodürik Enterococcus sp. ile Lactobacillus sp. bakterilerinin olması da beklenmekte, ancak geleneksel yoğurtların florasında Lactococcus sp., Leuconostoc sp. ve heterolaktik Lactobacillus sp. bakterilerinin bulunması bir gün önce üretilen yoğurdun (geleneksel starter kültür) kullanılmasından kaynaklandığı ve bu bakterilerin de geleneksel yoğurtların tat aromaları üzerinde etkili olduğu düşünülmektedir.

\section{Sonuç ve Öneriler}

Şanlıurfa ilinde satışa sunulan geleneksel yoğurtlar, yağ oranı bakımından Türk Gıda Kodeksi Fermente Süt Ürünleri Tebliği'nde belirtilen farklı sınıflar ile uygunluk arz ettiği, ancak süt yağının kısmi veya tamamen alınarak farklı şekilde değerlendirildiği sonucuna varılmıştır. Diğer taraftan, kırsal kesimde üretilen geleneksel yoğurt florasının istenmeyen kontaminant yüklerinin yüksek, LAB yüklerinin ise düşük olduğu tespit edilmiştir.

Kırsal kesimde yoğurt üretiminde kullanılan ve kara maya olarak bilinen bir önceki üretimden kalan yoğurt, aynı zamanda termofilik nitelikte geleneksel starter kültür tipidir (Soran ve Çelik, 2018). illgili mevzuat bağlamında (Anonim, 2011 ve 2017), kaliteli çiğ sütten üretilen kara maya (termofilik süt kültürü) ile ilgili bilimsel çalışmaların yapılması bölgesel yoğurt üretimi bakımından önem taşımaktadır. Bu bağlamda, bölge tüketicisinin yoğun talebinden dolayı, standart kalitede üretimin yapılamayacağı bilinmekle beraber, hijyenik şartlarda üretilen kara mayanın küçük ölçekli yoğurt üretimlerinde kullanılması, depolama, taşıma ve dağıtım aşamalarında soğuk zincire uyulması durumunda, geleneksel yoğurdun kontamine olmasını engelleyecek ve güvenilir şekilde tüketicilere ulaştırılmasını sağlayacaktır.

\section{Ekler}

Bu çalışma, Harran Üniversitesi BAP tarafından desteklenen (Proje no: 19121) Esra ÇETiN'e ait Yüksek Lisans Tezinden üretilmiştir.

Çıkar Çatışması Beyanı: Makale yazarları, aralarında herhangi bir çıkar çatışması olmadığını beyan ederler.

Yazar Katkısı: Şerafettin ÇELIK, araştırmayı tasarlayarak makalenin kavramsallaştırma, metodoloji, biçimsel analiz, yazma-inceleme ve istatistiksel analizine; Esra ÇETIN ise makaleye yazma-orijinal taslak, biçimsel analiz ve görselleştirmesine katkı sağlamıştır. Yazarlar makalenin son halini okumuş ve onaylamıştır.

\section{Kaynaklar}

Akarca, G. \& Tomar, O. (2019). Afyonkarahisar ili semt pazarlarında satılan süzme (kese) yoğurtların kimyasal ve mikrobiyolojik özellikleri. Akademik Gıda, 17(2), 212-216.

Albayrak, Ç. B. (2017). Antifungal Aktivite Üreten Laktik Asit Bakterileri. Adnan Menderes Üniversitesi Ziraat Dergisi, 14(1), 79-85.

Anonim. (2009). Türk gıda kodeksi fermente süt ürünleri tebliği. Gıda, Tarım ve Hayvancılık Bakanlığı, Tebliğ no: 2009/25, Ankara.

Anonim. (2011). Hayvansal gıdalar için özel hijyen kuralları yönetmeliği. Gıda, Tarım ve Hayvancılık Bakanlığı. Resmi Gazete Sayı 28155, Ankara: Tarih.

Anonim. (2017). Çiğ Sütün Arzına Dair Tebliğ. Gıda Tarım ve Hayvancılık Bakanlı̆̆ı. Tebliğ No: 2017/20, Resmi Gazete Sayı: 30050, Ankara.

Axelsson, L. (2004). Lactic acid bacteria: classification and physiology. In S. Lahtinen, A. C. Ouwehand, S. Salminen, A. Wright (Eds.), Lactic Acid Bacteria: Microbiological and Functional Aspects (Vol. 3, pp. 166). New York, USA: Marcel Dekker Inc.

Bakırcı, İ., Tohma, G. Ş. \& Yüksel, A. K. (2015). Erzurum piyasasında satışa sunulan yoğurtların fiziksel, kimyasal, mikrobiyolojik ve duyusal özelliklerinin incelenmesi. Akademik Gıda, 13(2), 127-134.

Caridi, A. (2003). Identification and first characterization of lactic acid bacteria isolated from the artisanal ovine cheese Pecorino del Poro. International Journal of Dairy Technology, 56(2), 105-110.

Carr, F. J., Chill, D. \& Maida, N. (2002). The lactic acid bacteria: a literature survey. Critical reviews in microbiology, 28(4), 281-370.

Ceylan, Z. \& Biberoğlu, Ö. (2013). Geleneksel olarak üretilen yoğurtların bazı kimyasal özellikleri. Atatürk Üniversitesi Veteriner Bilimleri Dergisi, 8(1), 43-51. 
Cogan, T. M., Barbosa, M., Beuvier, E., Binchi-Salvadori, B., Conconcelli, P., Fernandes, I., Gomez, J., Gomez, R., Kalantzopoulos, G. \& Ledda, A. (1997). Characterization of the lactic acid bacteria in artisanal dairy products. Journal of Dairy Research, 64(3), 409421.

Çetin, B., Atik, A. \& Karasu, S. (2014). Kırklareli'nde üretilen yoğurt ve ayranların fizikokimyasal ve mikrobiyolojik kalitesi. Akademik Gıda, 12(2), 57-60.

Demirci, A. \& Elvan, O. (2020). Sağlıklı ve Kaliteli Yoğurt Nasıl Mayalanır? Akademik Platform Helal Yaşam Dergisi, 2(1), 14-22.

Demirkaya, A. \& Ceylan, Z. (2013). Bilecik'te tüketime sunulan yoğurtların kimyasal ve mikrobiyolojik kalitesinin araştırılması. Atatürk Üniversitesi Veteriner Bilimleri Dergisi, 8(3), 202-209.

Durak, Y., Keleş, F., Uysal, A. \& Aladağ, M. O. (2008). Konya yöresi taze ev yapımı yoğurtların mikrobiyolojik özelliklerinin araştırılması. Selçuk Tarım Bilimleri Dergisi, 22(44), 113-117.

El-Diasty, E. M. \& El-Kaseh, R. (2009). Microbiological monitoring of raw milk and yoghurt samples collected from El-Beida city. Arab journal of biotechnology, 12(1), 57-64.

Gerasi, E., Litopoulou-Tzanetaki, E. \& Tzanetakis, N. (2003). Microbiological study of Manura, a hard cheese made from raw ovine milk in the Greek island Sifnos. International Journal of Dairy Technology, 56(2), 117122

Giraffa, G. (2003). Functionality of enterococci in dairy products. International Journal of Food Microbiology, 88(2-3), 215-222.

Göncü, B., Akın, M. S. \& Akın, M. B. (2017). Peynirde Biyojen Amin Varlığı ve Tespit Edilme Yöntemleri. Harran Tarım ve Gıda Bilimleri Dergisi, 21(1), 126-132.

Güler-Akın, M. B. (2005). The effects of different incubation temperatures on the acetaldehyde content and viable bacteria counts of bio-yogurt made from ewe's milk. International Journal of Dairy Technology, 58(3), 174179.

Halkman, A. (2005). Gıda Mikrobiyolojisi Uygulamaları: Başak Matbaacılık, Ankara, Türkiye, 358s.

Herdem, A. (2006). Farklı yörelerden toplanan geleneksel yöntemle üretilen yoğurt örneklerinin bazı niteliklerinin belirlenmesi. Selçuk Üniversitesi Fen Bilimleri Enstitüsü, Gıda Mühendisliği Anabilim Dalı, Yüksek Lisans Tezi, Konya, 97s.

Hisoğlu, E. (2007). Ağrı İlinde Tüketime Sunulan Yoğurtların Kimyasal ve Mikrobiyolojik Kalitesi. Yüzüncü Yıl Üniversitesi Sağlık Bilimleri Enstitüsü Besin Hijyeni ve Teknolojisi Anabilim Dalı, Yüksek Lisans Tezi, Van, $102 s$.

Karacaoğlu, Ş. (2018). Mahalli ve Ulusal Düzeyde Üretilerek Erzurum Piyasasında Tüketime Sunulan Yoğurtların Bazı Mikrobiyolojik, Fiziksel ve Kimyasal Özelliklerinin Karşılaştırılması. Atatürk Üniversitesi, Fen Bilimleri Enstitüsü, Yüksek Lisans Tezi, Erzurum, 51s.

Karahan, L. E. (2016). Batman'da tüketime sunulan yoğurtların bazı kimyasal ve tekstürel özellikleri. Batman Üniversitesi Yaşam Bilimleri Dergisi, 6(2/2), 59-65.

Kitazawa, H., Ishii, Y., Uemura, J., Kawai, Y., Saito, T., Kaneko, T., Noda, K. \& Itoh, T. (2000). Augmentation of macrophage functions by an extracellular phosphopolysaccharide from Lactobacillus delbrueckii ssp. bulgaricus. Food Microbiology, 17(1), 109-118.

Koçak, K. (2013). Tüketime Sunulan Yoğurtlarda Bazi Katki Maddelerinin (Nişasta, Jelatin, Natamisin) Kullanimi Ve Mikrobiyolojik Kalitesinin Belirlenmesine Yönelik Piyasa Araştirmasi. Afyon Kocatepe Üniversitesi, Fen Bilimleri Enstitüsü, Gıda Mühendisliği Anabilim Dalı, Yüksek Lisans Tezi, Afyon, 96s.

Kurt, A., Çakmakçı, S. \& Çağlar, A. (2014). Süt ve Mamulleri Muayene ve Analiz Metotları Rehberi: Atatürk Üniversitesi Ziraat Fakültesi Yayın No: 18, 238 s., Erzurum.

Mama, V., Hatzikamari, M., Lombardi, A., Tzanetakis, N. \& Litopoulou-Tzanetaki, E. (2002). Lactobacillus paracasei subsp. paracasei heterogeneity: The diversity among strains isolated from traditional Greek cheeses. Italian Journal of Food Science, 14(4), 351-362.

Moreno, M. F., Sarantinopoulos, P., Tsakalidou, E. \& De Vuyst, L. (2006). The role and application of enterococci in food and health. International Journal of Food Microbiology, 106(1), 1-24.

Nielsen, M. S., Martinussen, T., Flambard, B., Sørensen, K. I. \& Otte, J. (2009). Peptide profiles and angiotensin-Iconverting enzyme inhibitory activity of fermented milk products: Effect of bacterial strain, fermentation $\mathrm{pH}$, and storage time. International Dairy Journal, 19(3), 155-165.

Rasic, J. \& Kurmann, J. (1978). Yoghurt, fermented fresh milk products: Technical Dairy Publishing House, Copenhagen, Denmark.

Samaržija, D., Antunac, N. \& Lukač Havranek, J. (2001). Taxonomy, physiology and growth of Lactococcus lactis: a review. Mljekarstvo: časopis za unaprjeđenje proizvodnje i prerade mlijeka, 51(1), 35-48.

Schleifer, K., Kraus, J., Dvorak, C., Kilpper-Bälz, R., Collins, M. \& Fischer, W. (1985). Transfer of Streptococcus lactis and related streptococci to the genus Lactococcus gen. nov. Systematic and Applied Microbiology, 6(2), 183-195.

Sharpe, M. E. (1979). Identification Methods for Microbiololgists. In F. Skinner D. Lovelock (Eds.), Identification of the Lactic Acid Bacteria (pp. 244-259). London: Academic Press.

Soran, G. Ş. \& Çelik, Ş. (2018). Telemesi Haşlanan Geleneksel Peynirlerimizin Üretimine Uygun Doğal Starter Kültür Geliştirilmesi. Harran Üniversitesi Mühendislik Dergisi, 3(1), 15-19.

Sömer, V. F. \& Kılıç, G. B. (2012). Microbiological, physicochemical properties and biogenic amine contents of the strained yoghurts from Turkish local markets. African Journal of Biotechnology, 11(78), 14338-14343.

Spencer, J. F. \& de Spencer, A. L. R. (2001). Food microbiology protocols (Vol. 14): Springer Science \& Business Media.

Stiles, M. E. \& Holzapfel, W. H. (1997). Lactic acid bacteria of foods and their current taxonomy. International Journal of Food Microbiology, 36(1), 1-29. 
Şenol, K. \& Elvan, O. (2014). Yoğurtta lezzet bileşenlerinin oluşumu ve bu oluşum üzerine etki eden faktörler. Akademik Gıda, 12(2), 101-107.

Şimşek, Ö. (2015). Denizli ilinden toplanan çiğ süt ve peynirlerden otolitik laktik asit bakterilerinin izolasyonu, tanimlanmasi ve otolitik özelliklerinin belirlenmesi. (Yüksek Lisans Tezi), Pamukkale Üniversitesi Fen Bilimleri Enstitüsü Gıda Mühendisliği Anabilim Dalı, Denizli, 95s.

Tavşanlı, H., Gökmen, M. \& Önen, A. (2020). Balıkesir ilinde semt pazarlarında satışa sunulan yoğurtların fizikokimyasal ve mikrobiyolojik kalitesinin araştırılması. Balıkesir Üniversitesi Fen Bilimleri Enstitüsü Dergisi, 22(1), 318-326.

Tolu, A. (2019). Van Ilinde Farklı Noktalarda Satılan Ev Tipi Yoğurtlar ile Fabrikasyon Yoğurtlar Arasındaki Fiziksel, Kimyasal, Duyusal ve Mikrobiyolojik Özelliklerin Karşılaştırılması. (Yüksek Lisans Tezi), Van Yüzüncü Yıl Üniversitesi Fen Bilimleri Enstitüsü Gıda Mühendisliği Anabilim Dalı, Van, 96s.

Türkoğlu, H., Atasoy, A. F. \& Özer, H. B. (2003). Şanlıurfa ilinde üretilen ve satışa sunulan süt yoğurt ve Urfa peynirlerinin bazı kimyasal özellikleri. Harran Üniversitesi Ziraat Fakültesi Dergisi, 7(3-4), 69-76.
Üçüncü, M. (2005). Süt ve Mamulleri Teknolojisi: Ege Üniversitesi Mühendislik Fakültesi, Meta Basım Matbaacılık Hizmetleri, İzmir, 571s.

Veljovic, K., Terzic-Vidojevic, A., Vukasinovic, M., Strahinic, I., Begovic, J., Lozo, J., Ostojic, M. \& Topisirovic, L. (2007). Preliminary characterization of lactic acid bacteria isolated from Zlatar cheese. Journal of Applied Microbiology, 103(6), 2142-2152. Retrieved from

https://sfamjournals.onlinelibrary.wiley.com/doi/pdf direct/10.1111/j.1365-

2672.2007.03450.x?download=true

Vural, A., Erkan, M. E. \& Güran, H. Ş. (2010). The examination of the microbiologic quality in Örgü cheese (Braided cheese) samples. Kafkas Univ Vet Fak Derg, 16, S53S58.

Whittenbury, R. (1964). Hydrogen peroxide formation and catalase activity in the lactic acid bacteria. Microbiology, 35(1), 13-26.

Yaygın, H. \& Kılıç, S. (1993). Süt Endüstrisinde Saf Kültür Kullanımı: Altındağ Matbaacılık, İzmir, $108 \mathrm{~s}$.

Yıldız, N. \& Bircan, H. (1994). Araştırma ve Deneme Metotları: Atatürk Üniversitesi Ziraat Fakültesi Yayın No: 697, II. Baskı, Erzurum, 277s. 